\title{
Uma reflexão teórica sobre as noções de poder, controle e emancipação
}

Alejandra Astrid León Cedeño ${ }^{1}$

RESUMO: o poder é um conceito central na vida humana, porém tão complexo e polissêmico que faz referência a inúmeros autores, versões e conceitos associados a ele. Com o intuito de contribuir com a compreensão das múltiplas formas assumidas pelo poder, o presente artigo introduz este vocábulo, bem como as noções de dominação e controle; como necessária contraposição a elas, esboça-se o conceito de emancipação. Essa compreensão seria uma das ações possíveis desde o âmbito acadêmico para diminuir as formas de opressão que atravessam os processos e relações humanas e convertê-las em força emancipadora e afirmativa.

PALAVRAS-CHAVE: emancipação, poder, dominação, controle

ABSTRACT: The power is a central concept in human life, but it is a complex and polysemic word, that there is several authors, versions and concepts associated with it. In order to contribute to the understanding of the multiple forms assumed by power, this article introduces the term and the concepts of domination and control and outlines the concept of emancipation as opposed to them.

KEYWORDS: emancipation, power, domination, control

\footnotetext{
${ }^{1}$ Docente do Departamento de Psicologia Social e Institucional da Universidade Estadual de Londrina.Endereço: Universidade Estadual de Londrina. Rod Celso Garcia Cid.Pr $445 \mathrm{Km}$ 380. Campus Universitário. CEP 86055-900. Londrina PR. E-mail : aiasvenez@yahoo.com.
} 


\section{Por que discutir o poder}

“Com tanta gente pesquisando os movimentos sociais, sinto-me observado. Querem ajudar a gente? Pesquisem como funciona o poder, e contem-nos, para ver como podemos resistir a ele. Estudem o poder, vigiem o poder, não os ativistas!” (Militante catalão em Jornadas “Investigacció”, 28/01/04).

Dentre as mais diversas características estudadas na história das sociedades humanas, talvez a que tenha atraído a atenção de mais pesquisadores(as) de todas as ciências sociais seja o poder e, focalizando-o mais ainda, o poder enquanto sujeição ou dominação. Qualquer lista - mesmo que introdutória - de autores que tratam do tema assemelha-se a um guia do que são as próprias ciências sociais: Marx, Weber, Foucault, entre outros. De acordo com Tirado (2001), os estudos sobre o poder são tão importantes nas ciências sociais porque o tema é central na vida humana. Contudo, permanecem espaços inexplorados, imprecisões nas definições, coisas sem dizer. E provavelmente, apesar dos muitos estudos ainda por vir, continuará sendo assim.

Isso não é fortuito: as relações de poder e dominação são tão complexas e diversas que é quase impossível imaginar uma sociedade sem desigualdade alguma. Diz Passetti (2003) que não há como se desvencilhar completamente da autoridade e que, nas relações humanas, se vive uma tensão constante entre autoridade e liberdade. A tensão entre poder e potência, entre dominação e resistência, entre sujeição e agência (entre outras formas de nomear os dois pólos do conflito) deve ser discutida e aprofundada, para que o pólo da dominação possa ser diluído, enfraquecido, afirmando outros mundos possíveis. Esse ponto justifica o porquê deste artigo; um ponto explicitamente acadêmico/político - se é que há ponto acadêmico que não seja explicitamente político. A academia, no âmbito das ciências sociais, deve responder a pedidos como o do militante catalão citado acima; deve trabalhar na compreensão das múltiplas formas do poder, para poder informar como estas funcionam. O conhecimento acadêmico pode e deve ser usado para ampliar as possibilidades de que diferentes coletivos e pessoas - incluindo as da própria área acadêmica - aprendam mais sobre a dominação que as afeta e a transformem em rebelião, em força emancipadora e afirmativa (COLSON, 2003). 
Isso é diferente do que acontece atualmente. Como bem disseram os primeiros representantes da Escola de Frankfurt e como defende atualmente o filósofo português Santos (2003), o conhecimento científico produzido, que hoje constitui a forma oficialmente privilegiada de conhecimento, tem diminuído muito pouco o sofrimento humano e não tem construído um mundo justo nem belo. A promessa iluminista de gerar esse mundo a partir da racionalidade não se cumpriu.

A sujeição continua sendo construída a cada dia e, em determinados aspectos, tem aumentado. Todos e todas, acadêmicos(as) ou não, exercemos formas de opressão, dominação, controle, gestão, em relações de classe, raça, gênero, idade, necessidades especiais, opção sexual, peso corporal, entre outros. Algumas destas relações são sutis; outras, brutais. No meio, toda uma gama de pequenos a grandes horrores, cuja perversidade se aperfeiçoa dia a dia. Provavelmente a maior parte destas relações é exercida num âmbito restrito, no cotidiano de um lugar específico; porém, a composição de muitas delas produz efeitos que afetam seriamente a centos, ou milhares, ou milhões de pessoas. Santos coloca que, apenas no campo econômico, a diferença de rendimento entre o $20 \%$ da parcela mais pobre do planeta e o $20 \%$ da parcela mais rica era de 30 para 1 em 1960, foi a 60 para 1 em 1990 e já em 1997 estava em 74 para 1. Mais ainda,

"as 200 pessoas mais ricas do mundo aumentaram para mais do dobro a sua riqueza entre 1994 e 1998. A riqueza dos três mais ricos bilionários do mundo excede a soma do produto interno bruto dos 48 países menos desenvolvidos do mundo” (SANTOS, 2002, p. 07).

O atual mundo global, hipertecnológico, é cada vez mais desigual. E não é naturalmente assim. Nós o temos tecido desta forma nas nossas ações diárias. Portanto, para aprender a não repetir os mesmos erros, precisamos saber como temos feito isso, como funciona o poder.

Neste artigo, parte-se da noção de poder, esboçando que ela é ambígua por ser múltipla, situada em diferentes momentos e lugares históricos e necessariamente atrelada a uma concepção de sociedade, a uma postura política. A seguir, faz-se um resumo das suas diversas definições, ficando mais próximo das definições críticas que, posicionando-se a 
favor das pessoas oprimidas, entendem o poder enquanto dominação. Assim, o termo dominação é logo trabalhado, basicamente desde uma perspectiva frankfurtiana, e concordando com o argumento de que todas as formas de dominação devem ser constantemente questionadas e compreendidas para poderem ser revertidas, apenas aceitando-se provisoriamente alguma delas se isso responde a uma justificativa muito forte (CHOMSKY, 2004). Isso não é tarefa fácil: Adorno e Horkheimer (1985) alegam que a dominação se exerce utilizando-se da astúcia, e essa mesma astúcia dá lugar, na atualidade, a dinâmicas de controle cada vez mais sutis e perversas, na chamada sociedade global de controle (HARDT; NEGRI, 2000). Por isso, o termo controle é estudado, revisando o trânsito das sociedades disciplinares às sociedades de controle (FOUCAULT, 1976; DELEUZE, 1992; GUATTARI, 1984, 2004), e apontando para a importância da contribuição de Haraway (1995): frente a um poder - dominação que se mostra como cada vez mais desterritorializado, faz-se preciso situá-lo, localizá-lo em relações, momentos e lugares concretos do cotidiano.

\section{Sobre o conceito de poder: um panorama ambíguo}

O poder é um termo escorregadio. Carece de sentido esboçar "uma" maneira de entendê-lo: como bem diz Tirado (2001), este tema incorpora uma região inexplorada e incógnita na sua forma e formulação; apesar de ser um dos assuntos mais discutidos nas ciências sociais, as explicações acabam sendo insuficientes para compreendê-lo. A arena do poder aparece aqui como sendo movediça, complexa, imprecisa. Por isso começar-se-á a discussão sobre o conceito esboçando um panorama geral de por que ele é ambíguo.

Em recente revisão sobre o conceito de poder, Rojo (2005) propõe três motivos para argumentar sua ambigüidade: 1) ele implica em uma pluralidade de dimensões e é muito possível privilegiar algumas e esquecer outras; 2) ele se apreende através da experiência de sociedades particulares em um momento histórico específico, sendo que cada uma vive situações diferentes e 3) ele é inseparável da concepção de sociedade de quem o usa. Vale a pena se adentrar um pouco mais nestas razões.

Primeiramente, a noção de poder é ambígua porque implica em uma pluralidade de dimensões. Se tradicionalmente o vocábulo foi evocado para designar o Estado ou as pessoas que exercem o poder político, diversos(as) cientistas sociais questionam este uso 
restrito, apontando para a pluralidade de poderes que caracteriza as sociedades contemporâneas. Tal diversidade possibilita privilegiar alguma das dimensões em detrimento de outras, o que não seria difícil, considerando as muitas opções e combinações a serem abordadas. Quais seriam estas opções? Como primeiro exemplo, convém citar aquela que tem tido mais destaque, isto é, as relações de classe: a dominação pautada na propriedade foi uma marca fundamental na história humana e, segundo Crochik (2002), isso faz com que ela atravesse as outras relações de poder enquanto dominação, mesmo que este seja prévio à luta de classes e não se refira unicamente a ela.

Entretanto, muitos outros aspectos podem ser trabalhados. Pode se fazer alusão a relações mais explícitas ou mais sutis que se expressam ora em questões de modelos de governo, ora em práticas culturais ou institucionais, ora em aspectos que se expressam no cotidiano. As fronteiras entre estes temas não são claras e a multiplicidade de cada um destes aspectos apoia o argumento de que é praticamente impossível abordá-los todos por igual.

A fim de delinear mais claramente o campo-tema do poder, mencionar-se-ão alguns destes aspectos. Quanto a modelos de governo, conviria mencionar as discussões de Foucault (1978) e Rose (1996, 1999) sobre governamentalidade; o trânsito histórico de sociedades disciplinares a sociedades de controle (DELEUZE, 1992); as discussões gramscianas sobre hegemonia e sociedade civil; (GRAMSCI, 1978; SEMERARO, 1999); a compreensão de uma nova ordem mundial que funciona como Império (HARDT; NEGRI, 2000), como império mundial (PERKINS, 2005) ou Império Global Privatizado (EGO DUCROT, 2003); as discussões das ciências políticas sobre tomada de decisões e não-decisões políticas, ou definição da agenda política (LUKES, 1985), entre muitos outros. No relativo ao vasto campo das práticas culturais e institucionais, far-se-á alusão apenas ao trabalho da Escola de Frankfurt sobre a perversa dialética do esclarecimento, a dominação na ciência e o autoritarismo na sociedade; à proposta de Foucault (1976) sobre as formas de disciplinar o corpo na escola, na fábrica, nos hospitais, nos manicômios e em outras instituições; e também ao trabalho de Gramsci sobre os efeitos da escola (divisão entre escola profissional e ginasial-colegial como fratura entre subalternos(as) e dirigentes), a igreja (visão de mundo ensinada no catecismo), o serviço militar (manual do cabo), a mídia da época (jornais locais, rádio, cinema e romances seriados), episódios de cultura local e 
manifestações do folclore (contraste entre a "moralidade oficial" e a "moralidade popular", com marcas de rebeldia compartilhada).

Dentre os aspectos relacionados com o cotidiano, mesmo que, não necessariamente, sejam vinculados a ele de forma explícita (SPINK, 2004), aparecem, na América Latina e do Norte, os estudos de gênero, raça, idade e necessidades especiais, por exemplo, que têm trazido à tona relações de exclusão/inclusão e dominação (ROSEMBERG, 1984, 1996; SAWAIA, 1999; ANDRADE, 2001), constituindo-se em contribuições psicossociais às relações de poder. Na Europa, além dos trabalhos feministas (BUTLER, 1990), são relevantes, entre outros, os estudos culturais (MC ROBBIE, 1992) e sobre homossexualidade (LLAMAS, 1998), bem como os estudos queer (ROMERO BACHILLER, GARCÍA DAUDER e BARGUEIRAS MARTÍNEZ, 2005), que propõem alternativas pouco ortodoxas à dominação da moral sexual patriarcal, monógama e heterossexual. Não é à toa que se faz tão difícil estudar todas as dimensões por igual, sem discriminar nenhuma.

A segunda razão pela qual a noção de poder pode ser ambígua é que ela se apreende através da experiência de sociedades particulares em um momento histórico específico. Nesse sentido, como bem diz Lukes (1985), é possível criticar diversas concepções de poder, mas não se deve rejeitá-las como um todo: cada uma delas traz uma visão de sociedade, que pode não ser compartilhada, mas cuja presença deve ser reconhecida, porque diz algo a respeito dessa sociedade. Cada concepção se situa e encarna em relações que se dão em um tempo, um lugar, uma história, e o que faz sentido em um lugar pode não fazer em outro.

Em terceiro lugar, e em estreita relação com o motivo anterior, o poder não tem como ser politicamente neutro: é uma das noções mais dependentes da visão de sociedade que tiver o ou a cientista social que for usá-la. Tal idéia fica clara ao se comparar, como o faz Montenegro (2001), três concepções de sociedade como o são o funcionalismo, o marxismo e o anarquismo - que apenas serão mencionadas de forma sintética e limitada, sem fazer alusão à diversidade e divergências dentro de cada concepção. Cada uma delas implica uma noção de poder. A concepção de sociedade de Marx, por exemplo, é inseparável da sua concepção de dominação e luta de classes no modo de produção capitalista, que se dá devido à exploração que sofre o proletariado ao precisar vender sua força de trabalho aos 
proprietários dos meios de produção. No caso das propostas anarquistas, a sociedade também é entendida como sistema de dominação e autoridade, havendo acordo com o marxismo quanto à injusta exploração dos trabalhadores(as) e à necessidade de revolucionar o estado de coisas; no entanto, entre as formas de dominação criticadas se inclui a proposta marxista do Estado como mecanismo transitório para alcançar a sociedade sem classes nem Estado (SPINK, 1998), além de se criticar outras formas sociais de dominação como o machismo, a opressão das crianças e a alimentação carnívora.

Por outro lado, para os funcionalistas também há essa associação entre concepção de sociedade e de poder-dominação, mas o sentido dado a estes termos muda completamente: a sociedade é entendida através de uma metáfora biológica, como um corpo que, para funcionar corretamente, precisa de um cérebro que o comande, além de ter todos os seus órgãos e células funcionando em harmonia, em uma hierarquia natural (MONTENEGRO, 2001). O poder enquanto dominação seria, para a postura funcionalista, positivo e necessário para o bom funcionamento do coletivo.

As três razões de Rojo (2005) para compreender a ambigüidade dos conceitos de poder são úteis para se localizar no extenso panorama de estudos sobre o tema e para se posicionar criticamente a respeito. O primeiro dos seus motivos - pluralidade de dimensões do poder apoia o argumento de que as relações de poder - dominação são tão complexas e diversas que é quase impossível abordá-las todas e imaginar uma sociedade sem desigualdade alguma, o que pode ajudar a trazer autocrítica e observação cuidadosa das formas como se domina e se é dominado(a) no cotidiano.

O segundo motivo de Rojo - cada definição de poder responde a um contexto - leva a perguntar para as diferentes concepções o que elas estão relatando sobre as relações de poder no lugar e tempo específico em que foram formuladas, permitindo estabelecer nexos com outras sociedades e entendendo que determinados postulados não farão sentido em determinados contextos. O terceiro motivo, que é o de trazer implícita uma concepção de sociedade na noção de poder que se utiliza, implica, assim como os motivos anteriores, um posicionamento político e ético que se traduz - ou não - nas ações do dia-a-dia.

Com o intuito de aprender sobre essa diversidade de formas de poder - dominação para, conhecendo-as, aumentar a possibilidade de trabalhar na sua diluição, este artigo 
apresentará diversas noções de poder (algumas das quais o entendem como dominação e outras não) para depois apresentar as noções de poder enquanto dominação e controle, e finalizar com um conceito contrário: a emancipação.

\section{Poder: múltiplas definições}

Buscando situar os leitores e leitoras e organizar minimamente o emaranhado de definições sobre o poder, o compêndio de Rojo (2005) separa estas em três grupos: as voluntaristas, as sistêmicas e as críticas.

As definições voluntaristas situam-se na perspectiva de quem pode exercer o poder, enfatizando que tem mais probabilidades de concretizar seus objetivos e de impor sua vontade ou suas intenções. A mais citada destas definições é a de Max Weber, para quem Poder (Macht) significa a "probabilidade de impor a própria vontade, dentro de uma relação social, mesmo contra toda resistência e qualquer que seja o fundamento dessa probabilidade" (WEBER apud ROJO, 2005, p. 02). Outra definição nessa linha, freqüentemente evocada, é a de Robert Dahl: "A tem poder sobre B quando pode obter de B que faça algo que B, de outro modo, não teria querido fazer" (apud ROJO, 2005, p. 02). Segundo Rojo, na modalidade voluntarista encontram-se a maioria das definições sobre o poder: o autor localiza aqui as propostas de Bertrand Russell (1968, p.25), Dennis Wrong (1970, p. 02), Richard Henry Tawney (1952), James Mill (1825), Peter Blau (1964, p.117), Goldhammer e Shils (1939, p.173), Carl Joachim Friedrich (1963, p.61), Lasswell e Kaplan (1950, p. 70, 71, 75), William H. Riker (1964, p. 341-349), Nelson W. Polsby (1963, p. 34), Mokken e Stokman (1976, p. 37), François Chazel (1976, p. 65), Michel Foucault (1992, p. 134-137) e Pierre Birnbaum (1984).

Estas definições, ainda seguindo a Rojo, adotam a perspectiva "do ou dos donos do poder" (2005, p. 03), privilegiando a posição de quem pode usufruir do mesmo, e implicam uma assimetria entre essa posição e a daqueles que não exercem o poder, mas tal assimetria não é explicitada, nem são trabalhadas suas causas, nem tampouco os meios pelos quais é exercido o poder, nem as conseqüências desse exercício. Assim, quase todas estas definições apresentam-se como "neutras". Outrossim, elas conferem ao poder um caráter 
causal: é a fonte de ações ou omissões entre aqueles(as) submetidos(as) ao poder, e é o motivo pelo qual a vontade do(s) dono(s) do poder se concretiza.

As definições sistêmicas também se situam na perspectiva de quem exerce o poder, só que ele é entendido desde a perspectiva do sistema social, bem seja como causa do efetivo funcionamento do mesmo, ou como meio pelo qual o sistema alcança seus objetivos e cumpre suas funções (ROJO, 2005). Um exemplo clássico seria a definição de Talcott Parsons, para quem o poder é

a generalizada capacidade de assegurar o desempenho de obrigações por parte de unidades, num sistema de organização coletiva, quando as obrigações são legitimadas com referência ao seu impacto sobre metas coletivas e onde, no caso de recalcitrância, há um pressuposto de imposição de sanções de qualquer que seja a real agência daquela imposição (...) O poder de A sobre B é, na sua forma legitimada, o 'direito' de A, enquanto uma unidade de tomada de decisão envolvida em processo coletivo, tomar decisões que assumam precedência sobre aquelas de B no interesse da efetividade da coletiva operação enquanto um todo (apud LUKES, 1985, p. 24).

Para Lukes (1985), a conceituação de Parsons dissassocia-se dos conflitos de interesse e, em particular, da coerção e da força, estando seu foco na autoridade, no consenso e na busca das metas coletivas. Já de acordo com Rojo (2005), Parsons entende que o poder, implicitamente, permite a possibilidade de coerção, e ambos - poder e coerção - seriam legítimos dependendo do que aportam à obtenção das finalidades coletivas, inerente a toda organização social. Em consequiência, as obrigações das pessoas ou unidades - obrigações que não aparecem nas definições voluntaristas - permitem o exercício de poder e legitimam a possibilidade de coerção ou de sanções.

Com grandes diferenças entre si, mas entendendo o poder como meio para o sistema social funcionar adequadamente, outros autores se encontrariam dentro das definições sistêmicas. Para Rojo, eles seriam: Luhman (1982, p. 151; 1995, p. 09, 13), David Easton (1965), Karl Deutsch (1966), William Gamson (1968), Amos Hawley (1963, p. 422-431) e Roland Lynd (1957, p. 01-45). Apesar das diferenças entre eles, encontrar-se-iam na perspectiva funcionalista, na qual a ação do poder tenderia a estar marcada por um viés integrador e harmônico, que ocultaria sua dimensão conflitiva e assimétrica. 
Lukes (1985) afirma que essas definições colocam o foco no "poder de" e ignoram o "poder sobre". O poder, aqui, é visto como capacidade ou habilidade, não como relação. Com isso, desaparece o aspecto conflitual do poder - o fato de que ele é exercido sobre pessoas - e se esvai o interesse central de estudar em primeiro lugar as relações de poder.

Por último, as definições críticas fazem referência a uma concepção radical ou crítica, que foi inspirada pelo marxismo ou neo-marxismo (mas aqui cabem também formas de feminismo e anarquismo), e que define o poder em termos de dominação ou sujeição. Assim, diferenciando-se das concepções anteriores e criticando-as, estas definições adotam a perspectiva de quem padece o poder, mais do que a de quem o exerce. Para se entender o poder, faz-se necessário compreender "os conflitos de interesses que reinam em um contexto global de desequilíbrio das relações de força" (ROJO, 2005 p. 04). Nessa perspectiva, Rojo destaca aos autores Bachrach e Baratz e Steven Lukes. De um lado, Bachrach e Baratz (apud ROJO, p. 05) argumentam que o poder é exercido em benefício de certas pessoas ou grupos às expensas doutros. Ele implica a possibilidade, por parte daqueles em favor de quem opera este sistema, de tomar decisões que lhes convêm e limitar o campo das decisões possíveis dentro de fronteiras que garantam que seus interesses serão levados em consideração. Nesse ponto, os autores reivindicam a importância das "nãodecisões", injustamente deixadas de lado nos estudos sobre o poder.

Por outro lado, Lukes (1985), baseando-se em Bachrach e Baratz e em Nikos Poulantzas, define o poder como a possibilidade de exercer sobre outros uma ação em detrimento dos seus interesses. Dentro do mesmo conceito há muitos termos associados (força, coerção, manipulação, indução, encorajamento, persuasão, influência) em relações que se tecem em termos da existência ou não de um conflito de interesses e, se o houver, do fato de este ser observável (aberto ou encoberto) ou bem latente.

A noção dos interesses frustrados dos dominados levou a Lukes a insistir na relatividade do conceito do poder, entendendo-o como sendo "essencialmente contestado": não é possível estabelecer um consenso a respeito dele, pois faz referência a múltiplas visões de sociedade, a múltiplos lugares e momentos históricos, em uma polissemia na qual as diferentes versões ora coexistem sem maiores conflitos, ora estão envolvidas em tensões e lutas pelo sentido dominante. Entretanto, o autor defende que o poder tem um aspecto 
conflitivo: além de implicar em relações onde se exerce a capacidade de "poder-fazer" (HOLLOWAY, 2001a), se exerce em relações onde se constrói o "poder-sobre", a dominação.

\section{Dominação}

Seguindo a Rojo (2005), o conceito de poder é abstrato e geral demais (aplicável a qualquer situação) para servir, por si só, como elemento de análise das sociedades contemporâneas, e o próprio Weber, cuja definição de poder é a mais citada, propõe utilizar outro conceito, decorrente da noção de poder, só que mais específico e concreto: dominação (herrschaft). Esta seria o poder cristalizado de uma forma total ou parcialmente institucionalizada: é a forma como o poder se exerce efetivamente, seguindo regras conhecidas e aceitas; de fato, a legitimidade mais racional da dominação se encontra no Direito. Segundo Weber, ela pode definir-se como "a probabilidade de que um mandato seja obedecido" por se tratar de um poder socialmente legítimo para quem manda e para quem obedece (diriam Bachrach e Baratz que o conceito se refere às formas de A assegurar a concordância de B). A dominação deve ser aplicada a "relações sociais assimétricas nas quais a probabilidade de obediência a um mandato está formalizada até o ponto de poder manifestar certa estabilidade" (ROJO, 2005, p.06).

Assim, há relações de poder em todo lugar, perpassando todas as ações humanas, e a dominação é a cristalização dessas relações em momentos e lugares específicos, nos quais alguém fica definido como senhor/dominador e alguém como dominado/submisso (GONZÁLEZ BALLETBÓ, 2005). No entanto, isso não significa que a obediência à dominação seja harmônica ou necessariamente executada de bom grau. Pelo contrário, no presente trabalho há acordo com as definições críticas, que entendem os processos dominadores como desprover o outro da sua potência, esmagando-a, em relações construídas no cotidiano.

A respeito, a definição anarquista feita por Colson resulta pertinente. Para o autor, a dominação é uma "composição de forças coletivas na qual certas forças impõem a outras sua própria vontade, cerceando-as do que podem (da potência que portam consigo) e submetendo-as a uma ordem geral na qual estão separadas de si mesmas" (COLSON, 2003, 
p. 70). Qualquer ordem dominante (e, portanto, parcial) exige dos seres coletivos que não sejam mais do que são em um contexto específico (papel, função, lugar, identidade); que se restrinjam àquilo (COLSON, 2003, p. 235).

Esta definição, mesmo tendo um componente voluntarista - impor a própria vontade - é de base crítica: as forças dominadas são privadas da sua potência e limitadas à mesmice, à repetição do existente para reproduzi-lo; com isso, limita-se o campo possível de decisões e a tomada de decisões em si . Colocar o foco no cotidiano - ou fazer um zoom nele, como diria Spink (2005) - permite ver que não há uma cisão definitiva entre "os que têm o poder" e os que não. Como bem diz John Thompson (1995), uma mesma pessoa pode ser oprimida em um plano específico de ação e opressora em outro. As relações de dominação são complexas e assincrônicas, o que faz com que não haja divisão linear entre “dominadores(as)" e “dominados(as)". Todos(as) dominamos e somos dominados(as) em algum momento. Nesse sentido, diz Thompson que todos(as) temos poder, entendido enquanto capacidade de ação ou "poder fazer" - enquanto aquela força que cria realidades e materializa possibilidades. Entretanto, o poder se torna dominação quando o maior acesso a bens materiais e simbólicos é conseguido extirpando a potência do outro, ou como diria Holloway (2001a), quando o "poder fazer" vira "poder sobre".

Nesse sentido, daqui em diante utilizar-se-á a palavra dominação de modo a apontar com nitidez o "poder sobre" que exercemos dia a dia e que é preciso diluir para poder construir uma vida plena. A dominação perpassaria as relações humanas e estaria impedindo essa plenitude, apesar dos avanços tecnológicos e científicos da cultura patriarcal ocidental. E justamente as formas pelas quais a dominação se faz parte imanente da vida não têm sido detidas porque, como diz a rede venezuelana de cooperativas CECOSESOLA (2001), elas formam parte constitutiva da "nossa cultura" e dos seus pressupostos do que viria a ser a boa vida e a boa ciência. A racionalidade e a prevalência do econômico, propostas como pilares culturais fundamentais no Ocidente, parecem ser projetadas também nas formas de se conceber a dominação, deixando de lado outros processos igualmente importantes mas menosprezados ou silenciados pelas relações sociais e científicas hegemônicas. A respeito, bem comentava Rosemberg (2002) que "nós, intelectuais de esquerda, temos um ranço de considerar que todos os processos de dominação são conscientes (racionalistas, planejados, conspiratórios) e passam pelo econômico". Talvez a dominação faça parte da racionalidade 
burguesa ocidental até o ponto de perpassar a forma como é estudada a própria dominação. Sendo assim, é preciso mergulhar nessa racionalidade para, compreendendo-a, poder diluir a sujeição.

Ao se chegar nesse ponto, não há dúvida da importância de citar o trabalho da Escola de Frankfurt, já que é possível dizer que o centro das preocupações intelectuais dos membros da sua primeira geração - Adorno, Horkheimer, Marcuse e Benjamin - é o tema da dominação. Tendo vivido um período histórico onde prevaleceu o horror nazi-fascista e stalinista, os autores argumentavam que ele poderia repetir-se, tendo em vista que o modelo societário burguês, pautado na dominação, perdura tal qual; ele contradiz, portanto, seus próprios ideais de justiça, liberdade e igualdade, que não podem realizar-se em uma sociedade desigual, pautada pela acumulação de capital - e de conhecimento e hierarquia. Efetivamente, a preocupação dos autores era pertinente, como o mostram genocídios como o de Ruanda em 1994 (quase um milhão de pessoas) de Camboja o inclusive os ataques do próprio Estado de Israel à faixa de Gaza, entre muitos outros.

Face a tais horrores, a questão desses autores seria: se nós, seres humanos, conseguimos desenvolver uma tecnologia que possibilitaria a efetivação de uma sociedade justa e livre, por que, em vez de passar a essa outra forma de vida, nós regredimos? Por que não vamos mais além? Por que, se já é possível a liberdade, queremos ser felizes no aprisionamento? Assim, os estudos frankfurtianos pretendem mostrar o que nos impede de ser livres e nos leva à regressão.

É exatamente esse, para eles, o desafio central da contemporaneidade: não nos contentarmos com o estado de coisas desta sociedade, para assim poder construir outra. Na civilização ocidental não podemos criar um mundo efetivamente justo nem livre; apenas um pouco menos injusto. Precisamos, portanto, aprofundarmo-nos nas mazelas atuais para um dia romper com elas, implodindo-as. Em termos usados por Adorno e Horkheimer (1985), o que resta ao esclarecimento fazer agora é superar a dominação. Se ela foi forte, não tem mais por que ser. Não deve ser entendida como inerente ao ser humano. Até o momento nossa história foi a da violência, e ela tem servido a necessidades humanas, mas não teria por que continuar sendo assim. Foi talvez uma necessidade cultural que ela acontecesse - deve haver ocorrido alguma catástrofe histórica que levou a história humana 
por esse caminho, pois nada o justificaria; nada no ser humano indica que isso teria que acontecer. Contudo, não foi casual que acontecesse. As forças que fizeram com que nossa história resultasse nisso não teriam existido se não fizessem parte da natureza humana ${ }^{2}$. Seguindo esse argumento, a necessidade da dominação é o que deve ser combatido nas organizações sociais, em cada pessoa, em todo momento. Paz, felicidade e liberdade apenas são possíveis abrindo mão da dominação.

Esse raciocínio vai além da lógica economicista que atravessa "nossa cultura patriarcal ocidental", e que inclusive influencia as maneiras de se entender a dominação. De fato, Crochik (2002) defende que os frankfurtianos vão além de Marx e sua concepção do ato de subjugar a partir da luta de classes, isto é, da cisão e conflito entre dominantes e trabalhadores(as): para esses autores, a dominação apresenta diversas formas - como por exemplo, gênero, raça, idade, necessidades especiais... - que são atravessadas pela questão das classes sociais, pois a efetivação da idéia de propriedade privada marcou um momento fundamental na história humana. No entanto, sujeitar o outro é algo prévio à própria sociedade de classes. Não só isso: se para Marx cabia à classe trabalhadora apropriar-se dos meios de produção, fazendo uma revolução que possibilitaria a criação da sociedade sem classes, os primeiros membros da Escola de Frankfurt afirmam que tanto trabalhadores(as) quanto donos(as), hoje, estão presos à lógica perversa do capital. Diz Crochik (2002): “O proletariado foi cooptado; não cabe esperar dele fazer a revolução, se opor ao capital. Precisa-se de todos, não só dos trabalhadores".

Se trabalhadores(as) e dominantes, homens e mulheres, negros e brancos, são cativos da racionalidade instrumental burguesa que permeia as relações sociais, é fundamental estudar tal racionalidade. É o que Adorno e Horkheimer fazem na sua "Dialética do Esclarecimento", de 1944, traduzida em 1985. Nela, sustentam que essa ratio baseia-se na autoconservação, e relaciona-se com o conceito de esclarecimento - que seria, simultaneamente, uma forma de libertação do ser humano pela razão, mas também uma forma de reagir à ameaça existente: se submeter (à natureza) para dominar. Ao subjugar e

\footnotetext{
2 A respeito do termo "natureza humana", Chomsky (2004, p. 85) diz que ela "tem sido vista como algo reacionário, mas isso deve ser o resultado de uma profunda confusão. A minha neta não é diferente de uma pedra, de uma salamandra, de um frango ou de um macaco? Uma pessoa que concorda com isso reconhece que existe uma natureza humana distinta". Contudo, para evitar discussões que escapam a este trabalho, pode se usar a expressão "modos humanos" ou "maneiras de ser humano".
} 
controlar, o ser humano evita qualquer reação do objeto que gera perigo; tenta, assim, ter tudo previsto de antemão, não deixar nada de fora, pois é o inesperado que gera o terror; e quando este ser humano, enquanto sujeito de conhecimento, pretende sujeitar o objeto às suas próprias disposições e leituras, acaba violentando-o. Assim, o raciocínio autoconservador faz com que abominemos qualquer tipo de fragilidade (na natureza) porque nos recorda a nossa própria fragilidade. Tal debilidade diante do mundo, porém, acaba sendo nossa força: ela dá lugar à astúcia, necessária para poder sobreviver.

Ao mesmo tempo, o aspecto libertador do esclarecimento - construir, graças à razão e à aquisição de conhecimentos, um mundo livre, igualitário e justo - não é acessível a todos os seres humanos: o burguês evita que ele seja universalizado para manter o próprio poder; e o que é visto como natureza a ser dominada passa a ser a maioria oprimida. Assim, nas chamadas "minorias" (mulheres, negros(as), índios(as), pobres, necessidades especiais, judeus/judias -e atualmente é pertinente citar o povo palestino) é colocado o estigma da natureza, fazendo-se, portanto, uma redução destas categorias para o natural. Tais "minorias", então, são vistas como natureza que deve ser submetida. Deduz-se daqui que a sociedade permite e legitima a perseguição de minorias ao aprisioná-las neste estigma. Nesse sentido, Crochik (2002) é enfático quando diz que "se, hoje, alguns alvos são libertados, é para poder perseguir outros. O que não muda é a perseguição, calcada na ameaça que vem do primitivo, e que a burguesia acaba reproduzindo quando pretende lutar contra isso".

A lógica dominadora, então, se expressa na necessidade de defender-se do terror do desconhecido - ou do diferente - subjugando-o, vendo nele a própria fragilidade que quer se esmagar, e esmagando-o. E quando isso não é possível, quando as circunstâncias são mais fortes que nós, procuramos dominá-las astutamente mediante nossa própria submissão, inventando estratagemas que permitam nossa autoconservação. Estas noções são fundamentais para entender a violência na atualidade, que borbulha e se reproduz com uma rapidez que a mídia nos vende como estando desvinculada das condições sociais que vivemos, e como sendo um fenômeno muito recente, quando na verdade vem se gestando desde séculos atrás na história humana e agora simplesmente se faz mais evidente e cruel. Bem aponta CECOSESOLA (1991) a coerência da empresa do tráfico de drogas com a 
lógica que hierarquiza, acumula e particulariza. À luta - do burguês e do tráfico - por dominar e controlar soma-se uma nova estratégia: a astúcia.

Aparentemente, para Adorno e Horkheimer, a astúcia burguesa que possibilita a sobrevivência começou com o mito grego da Odisséia de Ulisses, rei de Ítaca, que entre outros feitos, burlou o líder dos ciclopes, gigantes de um único olho e inteligência escassa, se auto-chamando de Ninguém e agindo nas sombras. Só que, mediante o constante cálculo que a astúcia pressupõe, renuncia-se a uma vida plena, que é o ideal que se pregoa.

Para os frankfurtianos, então, as relações de dominação foram construídas historicamente nas relações humanas, são "encarnadas" no cotidiano e, até provar o contrário, estão impedindo a construção de um mundo justo e uma vida bela; portanto, devem ser constantemente questionadas e compreendidas para poderem ser revertidas, apenas aceitando-se provisoriamente alguma delas quando serve para dominar nossa própria dominação: se todas as pessoas estamos atravessadas pela dominação, precisamos fazer consciente esse desejo para dominá-lo e assim fazê-lo desaparecer.

Não se sabe como a humanidade enveredou pelo caminho da dominação - e provavelmente seja inútil fazer-se essa pergunta, tal a multiplicidade de formas de subjugação e a vastidão de respostas possíveis, não necessariamente coerentes entre si. Mas, se escutamos a Adorno neste ponto, podemos dizer que alguma catástrofe histórica nos fez seguir esse caminho, que não é o único possível nem o melhor. Para afirmar que não o é, faz-se importante mostrar o sofrimento humano que tem sido gerado e perguntarmo-nos o porquê -ou o para que - desse sofrimento, buscando argumentos que permitam responder essa pergunta de forma situada e responsável. Assim, em vez de conformar-nos com o existente, devemos negá-lo. Negarmos o atual estado de coisas e também as concepções de ser humano, sociedade e conhecimento, assumindo que elas não são naturais nem justas. Mas trata-se de negar o existente afirmando a possibilidade de construir uma vida plena e uma sociedade justa e livre. Em vez de ficarmos presos ao ressentimento - por termos sido dominados(as) - ou da culpa - por termos sido dominadores(as) - , rebelamo-nos para romper as ataduras da dominação, abrindo mão dela e afirmando outra composição do mundo.

Resulta fundamental negar a dominação, por pequena que seja, para combatê-la. Para poder negá-la, para poder enfrentá-la e diluí-la, é fundamental entender cada vez mais como 
funciona. Não é preciso ser um perito em entender as complexas dinâmicas da sujeição para criar alternativas ao mundo existente - até porque, como diz Adorno (1991), somos cindidos e, embora pareça absurdo, podemos pensar no indivíduo sem a sociedade, na resistência sem a dominação. Contudo, a emancipação mais potente só é possível ao se nomear a tutela opressora, observando-a e entendendo-a para superá-la. É vital situar as formas como opera a dominação (HARAWAY, 1995), entendê-la nos meandros do dia-adia, assim como nas práticas cotidianas das relações entre grandes corporações, bancos, governos, cujas conseqüências se espalham por todo lugar e provavelmente não estão muito distantes de nós. E também é importante assumirmos a responsabilidade de entendê-la no cotidiano acadêmico: quando o saber científico se constitui enquanto forma dominadora de entender o mundo, de exercer dominação sobre seu "objeto" de estudo, restringe as possibilidades de contribuir na construção de um mundo sem sujeição (ADORNO; HORKHEIMER, 1985; SANTOS, 2003).

Contudo, para entender-se a dominação hoje há um desafio ainda maior: nas complexas sociedades atuais se constroem formas cada vez mais astutas e sutis de exercer poder. As formas dominadoras de esmagar a potência do outro coexistem com mecanismos de captura dessa potência, pondo-a a trabalhar em todos os aspectos da vida para gerar benefícios o tempo inteiro. Tirado (2001) postula que passamos cada vez mais da dominação ao governo, à gestão mediante o controle: dominar consistia - ou consiste - em ignorar ou eliminar a capacidade de ação de quem é dominado(a), mas governar exige reconhecer essa capacidade de ação (ou poder - fazer) das pessoas governadas e ajustar-se a elas. Governar é agir sobre a ação, geri-la, colocá-la em direção aos próprios objetivos.

Os processos de governo exercidos mediante o controle podem ser denominados como governamentalidade (FOUCAULT, 1978; ROSE, 1996, 1999). As práticas cotidianas de poder enquanto dominação e controle são o foco deste texto, e não os diversos conceitos atrelados ao exercício do poder, mas vale a pena situar o termo controle citando o que, para o grupo de pesquisa "Fractalidades en Investigación Crítica" (FIC, 2005) significa governamentalidade:

“A noção de governamentalidade (FOUCAULT, 1978; RIVERO, 2004) mostra como historicamente se consolidam práticas institucionais de governo, tais como a vigilância, inspeção, 
legislação, regulação, controle, doutrinação, avaliação, censura, prevenção, retificação, correção, quer dizer, 'um conjunto de práticas por meio das quais pode se constituir, definir, organizar, instrumentalizar a s estratégias que as pessoas, nas suas liberdades, estabelecem em relação com as outras’ (MEDRADO, 2002).

Os projetos dentro do campo da psicologia e da psiquiatria, por exemplo, têm configurado critérios de normalidade que geram categorias desde as quais tipifica-se a experiência vivida pelos sujeitos e sob as quais os sujeitos se definem. Esta ação de governo age desde o exterior e o interior da pessoa a partir dos parâmetros de normalidade estabelecidos institucionalmente, dos quais a empresa científica participa ativamente. As necessidades de governo das sociedades (neo)liberais atuais requerem uma gestão da subjetividade que produza indivíduos que livremente auto geram suas vidas no espaço 'público', sob parâmetros de governamentalidade estabelecidos. É central, portanto, a existência de uma rede de compreensões e significados que permitam tornar invisíveis as redes institucionais para gerar a sensação de liberdade de eleição (ROSE, 1996). O desenvolvimento de formas cada vez mais sofisticadas de sujeitar física e simbolicamente as pessoas se dá junto com a expansão de um tecido de saberes disciplinares (FOUCAULT, 1976) dedicados à recopilação, desenvolvimento e transformação destas práticas de governo. As democracias liberais ocidentais e sua forma de produção pós-fordista combinam liberdade aparente com fortes mecanismos mais ou menos invisibilizados de controle, levando à implantação crescente e cotidiana de múltiplos mecanismos de bio-poder sobre âmbitos crescentes da vida e as populações" (FIC, 2005, p. 03).

Enquanto a governamentalidade é o conjunto de dispositivos de governo, o controle é uma forma específica e atual de exercer a governamentalidade. Vejamos, então, o que controle significa e quais suas implicações. 


\section{Controle}

Sou livre...

Posso eleger o banco que me exprima, o canal de TV que me embruteça,

A petroleira que me saqueie, a comida que me envenene, a rede telefônica que me estafe, o informador que me desinforme e a opção política que me desiluda.

Insisto: sou livre. (Consulta Social Européia, 2004).

No Dicionário Aurélio, Ferreira define controle como "ato ou poder de controlar, domínio, governo; fiscalização exercida sobre as atividades de pessoas, órgãos, departamentos, ou sobre produtos, etc., para que tais atividades, ou produtos, não se desviem das normas preestabelecidas" (1995, p. 176). O controle seria uma forma específica de exercer poder, uma forma concreta de governamentalidade, em cuja importância coincidem diversos autores(as) aqui utilizados(as): Hardt e Negri (2000), Deleuze (1992), (1976), Passetti (2003), Balasch (2005), CECOSESOLA (2001) e, em certo sentido, Adorno e Horkheimer (1985). O controle parece, então, um conceito central para entender as dinâmicas de poderdominação atuais, e o uso que dele é feito aqui e por vários autores citados acima se fundamenta em uma proposta foucaultiana: a do trânsito da sociedade disciplinar à sociedade de controle, de modo a se governar mais eficaz e sutilmente.

Conforme Deleuze (1992), Foucault situou as sociedades disciplinares nos séculos XVIII, XIX e no início do século XX, quando atingiram seu apogeu. Elas se configuram na organização das instituições que operam como grandes meios de confinamento, e que vão tornando os corpos dóceis à medida que o indivíduo passa a vida inteira indo de um espaço fechado a outro, cada um com suas leis, que devem ser obedecidas: a família, a escola, a fábrica, eventualmente o hospital, a prisão (meio de confinamento por excelência), o manicômio, o asilo. O modelo disciplinar sucedia ao das sociedades de soberania e, aparentemente, a transição de um ao outro foi progressiva e culminou com o governo de Napoleão. Os meios de confinamento tinham o objetivo, particularmente visível na fábrica, de "concentrar, distribuir no espaço, ordenar no tempo, compor no espaço-tempo uma força 
produtiva cujo efeito deve ser superior à soma das forças elementares" (DELEUZE, 1992, p. 219).

Contudo, a preponderância das sociedades disciplinares seria breve: novas forças iam se erguendo lentamente, precipitando-se após a Segunda Guerra Mundial. Hoje, os espaços de confinamento, desde a família até o asilo, estão em crise. Constantemente os governantes falam de reformá-los: reformar a escola, o hospital, a indústria, o exército, a prisão. Mas eles, diz Deleuze, estão condenados. Forças novas surgem e vão coexistindo com as disciplinas e substituindo-as. São as sociedades de controle.

Enquanto as sociedades disciplinares se fundamentavam na obediência, na dominação exercida vigiando e punindo, nas sociedades de controle os mecanismos de comando se tornam cada vez mais "democráticos", distribuídos pelos corpos e cérebros dos cidadãos e cidadãs. O poder passa a ser exercido através de "máquinas que organizam diretamente o cérebro - em sistemas de comunicação, redes de informação, etc. - e os corpos - em sistemas de bem-estar, atividades monitoradas etc." (HARDT; NEGRI, 2000, p.42). No controle, os mecanismos disciplinares que constroem as normas das nossas práticas cotidianas, se intensificam e generalizam, estendendo-se para muito além das instituições sociais, em redes flexíveis e flutuantes.

Assim, as sociedades de controle podem ser entendidas como fluxos contínuos flexíveis (PASSETTI, 2003). São contínuos porque nunca se termina nada: a empresa substitui a fábrica, a formação permanente tende a substituir a escola, a avaliação contínua substitui as provas, o trabalho por projetos substitui a estabilidade no emprego e a certeza da aposentadoria. São flexíveis porque as estratégias mudam e a rigidez se esvai, dando passo à tolerância se ela for útil para a produção e o controle crescerem: capturam-se as particularidades culturais, as habilidades afetivas, a cooperação, o trabalho em equipe, a criatividade, a rápida resposta aos imprevistos, a possibilidade de personalizar o lugar de trabalho (CALLÉN, 2005), ao mesmo tempo em que, quando é conveniente, emula-se a competição e a individualidade como elementos de motivação (DELEUZE, 1992).

Essas formas de funcionamento são úteis em meio a relações econômicas específicas, que Deleuze ajuda a compreender quando diz que 
Atualmente o capitalismo não é mais dirigido para a produção, relegada com freqüência à periferia do Terceiro Mundo, mesmo sob as formas complexas do têxtil, da metalurgia ou do petróleo. É um capitalismo de sobre-produção. Não compra mais matéria-prima e já não vende produtos acabados: compra produtos acabados, ou monta peças destacadas. O que ele quer vender são serviços, e o que ele quer comprar são ações. Já não é um capitalismo dirigido para a produção, mas para o produto, isto é, para a venda ou para o mercado (...). O marketing é agora o instrumento de controle social, e forma a raça impudente dos nossos senhores. O controle é de curto prazo e de rotação rápida, mas também contínuo e ilimitado, ao passo que a disciplina era de longa duração, infinita e descontínua. O homem não é mais o homem confinado, mas o homem endividado. É verdade que o capitalismo manteve como constante a extrema miséria de três quartos da humanidade, pobres demais para a dívida, numerosos demais para o confinamento: o controle não só terá que enfrentar a dissipação das fronteiras, mas também a explosão dos guetos e favelas (1992, p. 225).

Deleuze se refere a operações econômicas, sociais e políticas que apontam para a totalidade do planeta, no que Hardt e Negri (2000) denominam a sociedade global de controle, e Guattari (1984) o capitalismo mundial integrado, no contexto do que inúmeros autores e autoras chamam globalização. O que nas dinâmicas de poder e dominação muda com a dita sociedade globalizada? Até que ponto há mudanças? Embora a globalização não seja o foco deste texto, é uma palavra que não pode ficar indiferente ao se escrever sobre o poder na atualidade. Por isso esboçar-se-ão breves linhas sobre ela.

De acordo com Santos (2000) e Matta (2005), o marco político da chamada globalização encontra-se na década de 80, durante o Consenso de Washington, constituído por instituições financeiras de ajuda internacional norte-americana como o Banco Mundial, O Fundo Monetário Internacional e o Banco Interamericano de Desenvolvimento. Neste documento, realizaram-se prescrições para a reestruturação econômica da América Latina, visando o ajuste estrutural monetário através de "ajustes fiscais, redução do papel do Estado 
na economia, privatização dos serviços públicos, liberalização dos investimentos estrangeiros, direito à propriedade e redução dos investimentos nas políticas sociais" (MATTA, 2005, p. 49).

Essa história pode ser lida de formas radicalmente diferentes, como discute Balasch (2005). Desde a postura dos(as) analistas de negócios, o temo "globalização" se refere à abertura, à escala global, dos mercados de capital financeiro e de mercadorias, o que implicará na melhoria das condições de vida das pessoas do mundo. Portanto, as formas de produção e troca do sistema capitalista devem ser espalhados por todos os países do planeta. Os denominados "países de terceiro mundo" devem incorporar-se a este movimento praticando o já mencionado ajuste estrutural monetário, já que seus problemas atuais - pobreza generalizada, guerras, desemprego etc. - são atribuídos a que seus governos locais, injustos e corruptos, se negam a "mundializar" suas economias. Nessa leitura, a mundialização seria a solução. Para os "países de terceiro mundo" poderem, então, superar estes problemas, recebem a "ajuda" do FMI, Banco Mundial, Organização Mundial do Comércio, instituições técnicas que formulam Planos de Ajuda Estrutural recomendando aos Estados que adotem medidas políticas, econômicas e sociais necessárias para sua incorporação à lógica global. Isto é o que Rojo (2005) entenderia como sendo uma concepção sistêmica do poder e uma noção funcionalista de sociedade, onde não se discutem as dimensões conflitivas destas relações e se entende a ordem mundial como um organismo que precisa de todas suas partes seguindo o mesmo comando para funcionar em harmonia.

Por outro lado, alguns teóricos/as das ciências sociais, partindo de uma perspectiva crítica para se entender o poder e a sociedade, estudam as conseqüências sociais da era da "globalização": seriam as mesmas conseqüências negativas do capitalismo e sua lógica de acumulação contínua, mas no nível mundial, fazendo-se presente em mais lugares (em uma extensão maior) e com uma intensidade voraz, trazendo desigualdades sociais abismais como seu efeito mais imediato. Balasch (2005, p. 35) resume as características mais destacadas por vários autores(as):

- Incremento das desigualdades entre pessoas "ricas" e "pobres", tanto no nível internacional (países "do primeiro mundo" - países do "terceiro mundo") como no nível nacional (desigualdades entre grupos sociais em uma mesma sociedade); 
- Incremento das migrações produto, justamente, dessas desigualdades;

- Destruição do tecido social e cultural como conseqüência da homogeneização das formas de produção e estilos de vida no nível global;

- Perigos associados à destruição do meio ambiente (GEORGE, 2001);

- Incremento da divisão do trabalho e das desigualdades sociais e aparição de perigos globais - do meio ambiente, sociais e militares (BECK, 1997);

- Incremento da mobilidade, a flexibilidade e o "tornar-se nômade" das condições de vida, transformando assim os membros das sociedades globais, que passam a ser de cidadãos a consumidores (BAUMAN, 1998);

- Enfraquecimento do poder político dos Estados-Nação especialmente os do "terceiro mundo" devido à implantação dos Planos de Ajuda Estrutural, que "recomendam" minimizar os gastos públicos (VAQUERO, 1999);

- Irrupção da sociedade em rede a partir da emergência das tecnologias da informação e o conhecimento (MELUCCI, 1996; CASTELLS, 1994). A anulação tecnológica das distâncias temporais e espaciais tende a polarizar a condição humana, mais que a homogeneizá-la. A velocidade que com a irrupção das novas tecnologias tem impregnado as sociedades globais está incrementando as desigualdades sociais (BAUMAN, 1998, apud BALASCH, 2005, p. 35).

De acordo com estas posturas, então, o processo de mundialização da economia, ao invés de produzir melhoras substanciais nas condições de vida das pessoas, produz exploração, exclusão e pobreza: seguindo a própria lógica capitalista, é impossível gerar o "desenvolvimento" do mundo todo, pois para alguns setores se "desenvolverem", outros precisam ficar “subdesenvolvidos” (AMIN, 1974, apud BALASCH, 2005). 


\section{Como funciona o poder na sociedade global de controle}

Hardt e Negri (2000) propõem que a sociedade globalizada se constitui mediante a produção e o incremento de conexões entre os mais diversos aspectos da vida: econômicos, políticos, culturais, tecnológicos, administrativos e jurídicos. Em meio a este "tecido", surgem novas formas de governamentalidade - ou gestão de populações -, formas que também são misturas desses diversos aspectos, e que combinam controle social e disciplina em âmbitos sociais cada vez mais amplos e profundos, penetrando o cotidiano de forma crescente. Práticas como as atividades domésticas, o esporte, a cultura e os modos de produção marginais, que tinham se mantido mais afastados do mercado mundial, estão caindo na dependência do mesmo. O capitalismo está colonizando o planeta inteiro (GUATTARI, 2004). As redes da sociedade global integram a totalidade da vida, tecendo e capturando múltiplos âmbitos, e já não é possível permanecer fora dela.

Essa idéia, segundo Hardt e Negri, vem da proposta de Foucault que permite reconhecer a natureza biopolítica do poder. O biopoder seria a forma de poder que se ocupa da produção e reprodução da própria vida, regulando e administrando a vida social por dentro (e, nela, a intimidade e sexualidade), a partir da produção de regimes de verdade que regulamentam as populações humanas; e que pode se desenvolver plenamente apenas na sociedade de controle:

A disciplinaridade fixou indivíduos dentro de instituições mas não teve êxito em consumi-los completamente no ritmo das práticas produtivas e da socialização produtiva; não chegou a permear inteiramente a consciência e o corpo dos indivíduos, ao ponto de tratá-los e organizá-los na totalidade de suas atividades. $\mathrm{Na}$ sociedade disciplinar, portanto, a relação entre o poder e o indivíduo permaneceu estável: a invasão disciplinar de poder correspondeu à resistência do indivíduo. Em contraste com isso, quando o poder se torna inteiramente biopolítico, todo o corpo social é abarcado pela máquina do poder e desenvolvido em suas virtualidades. Essa relação é aberta, qualitativa e expressiva. A sociedade, agrupada dentro de um poder que vai até os gânglios da estrutura social e seus processos de desenvolvimento, reage 
como um só corpo. O poder é, dessa forma, expresso como um controle que se estende pelas profundezas da consciência e dos corpos da população - e, ao mesmo tempo, através da totalidade das relações sociais (HARDT; NEGRI, 2000, p. 43).

Hardt e Negri afirmam que muitos (as) pensadores(as) seguiram Foucault nessa direção para problematizar, no âmbito europeu, o Estado de Bem-estar Social. Mas hoje, quando boa parte dos mecanismos sociais de bem-estar se esvai e se fortalece o modelo pós-fordista de governo e (re)produção capitalista, o biopoder chega além do esboçado por Foucault. Segundo Balasch (2005), este se espalha nas práticas cotidianas e, mais que colocar em jogo a produção e reprodução da vida, apaga as fronteiras entre o espaço/ tempo produtivo e o não produtivo. A vida inteira é posta a trabalhar na sociedade global. O modelo pósfordista produz não apenas mercadorias e benefícios de ordem monetária, mas subjetividades produtoras da máquina global - da privatização, do consumo como eixo social central, das demissões em massa, do trabalho sem registro em carteira, da guerra contra o terrorismo, do incremento das desigualdades sociais, entre outros.

Nestas circunstâncias o poder, em vez de funcionar como se entenderia tradicionalmente, ou seja, como uma substância que emerge em centros que podem ser localizados geograficamente, funcionaria de forma imanente e descentralizada. Guattari (1984), por exemplo, diz que o capitalismo global integrado tende ao que ele denomina "desterritorialização", isto é, a funcionar sem fixar-se em territórios nem âmbitos específicos, atravessando tudo. Por exemplo, em diversos países ditos desenvolvidos aparecem regiões do terceiro mundo, assim como em meio a países ditos subdesenvolvidos aparecem centros capitalistas de elite, constituindo assim um poder multicêntrico.

O poder não tem caráter universal e por isso pode se apoiar simultaneamente em regimes totalitários e democráticos, sempre que isso favoreça a homogeneização dos seus meios de produção, circulação e controle social. Portanto, não é programático e sim axiomático: para se manter, se utiliza dos meios que forem mais apropriados no momento, sem seguir uma linha de governo (GUATTARI, 1984). A forma de produção pós-fordista combina processos disciplinares e de controle; captura as competências importantes para controlar efetivamente indivíduos e populações (atividades de cooperação social, criação de 
pensamento, comunicação, afetividade) e as imbui nos canais da produção mercantilista; dá mais importância às habilidades dirigidas à produção de significados - e, portanto, de subjetividades - do que às formas de produção fordista, mas estas continuam tendo um peso inegável, mesmo que deslocadas para outros espaços geopolíticos em uma lógica de Primeiro-Terceiro Mundo (FIC, 2005). Em meio a essa heterogeneidade, contudo, Hardt e Negri (2000) reconhecem lógicas comuns: a militar e policial (repressão de potencialidades subversivas à paz global), a econômica (imposição de um mercado atrelado ao regime monetário, principalmente ao dólar) e a ideológica e comunicativa (supressão de alternativas ao capitalismo e regulamentação cultural e educativa).

A proposta de se entender o poder em termos de desterritorialização, imanência e descentralização tem em Foucault um pilar importante, pois desenvolve idéias foucaultianas como o trânsito da disciplina ao controle e o biopoder, além de ter uma forte herança do seu conceito de poder. Para Foucault (1976), o poder não se identifica em primeiro termo com a soberania do Estado, com a lei ou com a unidade global de uma dominação. Não é o conjunto de instituições que garantem a sujeição dos indivíduos, mas uma rede complexa de relações de poder que podem se produzir em todo e qualquer lugar. O poder não se adquire, nem se conquista, nem se compartilha ou se arranca, não se conserva nem se deixa ir: exerce-se a partir de inúmeros pontos e em relações móveis e não igualitárias. As relações de poder não são exteriores a outras relações, tais como as econômicas, as sexuais ou as do conhecimento: são imanentes a elas; se dão nas repartições, desequilíbrios e desigualdades que se produzem nestas relações e são efeito das mesmas. O poder não depende de uma oposição binária e global entre dominantes e dominados(as); em vez de gerar-se de cima para baixo, vem de baixo: as relações de poder imediatas, cotidianas, servem de suporte e dão condições às grandes relações de dominação. As relações de poder não surgem de decisões individuais, da casta que governa, daqueles que tomam as decisões políticas ou econômicas, nem de forças que manipulam a realidade de forma oculta: elas funcionam mediante táticas que se encadeiam umas com outras, tecendo inúmeros fios que, finalmente, desenham os dispositivos de conjunto, com uma lógica clara, a qual, paradoxalmente, já não pode se dizer que foi desenhada por ninguém, e há muito poucas pessoas que as formulam. 
A visão de Foucault é de uma utilidade ímpar para se aprender a não ver poder e resistência de forma cindida nem maniqueísta, em termos de bandidos e mocinhos. As relações de poder se criam em redes complexas que estão em todas as partes, que possibilitam uma maior regulação e controle dos corpos e das subjetividades, que determinam processos de governamentalidade, que organizam formas de vida (MATTA, 2005) e que, com o passar do tempo, tendem a se desterritorializar, desatrelando-se de territórios e mecanismos fixos, de pessoas específicas, de instituições concretas. Só que justamente esse lado da concepção torna mais difícil a localização do poder e, portanto, construir opções a ele; para se avançar na reconstrução responsável das formas de entender e conceber o mundo, isso deve ser revisto. Em palavras de Arditi,

a principal dificuldade do conceito de poder de Foucault jaz precisamente na sua incapacidade de localizar o poder e de vê-lo assim afetando e constituindo as pessoas de maneiras diferentes. Embora o poder penetrasse tudo, não tinha um agente. Sua leitura da história era, em conseqüência, uma leitura sem gênero, sem classe e étnica e racialmente neutra, que criava uma impressão de um corpo social amplamente homogêneo. Era difícil, se não impossível, ver como o "poder" poderia ser combatido (não apenas resistido), e era impossível desenvolver uma estratégia para conseguir uma visão de um futuro melhor" (1995, p. 16).

Entretanto, há propostas situadas para lidar com essa dificuldade, e epistemologias feministas como o trabalho de Donna Haraway (1995) contribuem nesse sentido. Arditi, falando da autora no prefácio do livro "Ciência, cyborgs y Mulheres", diz que Haraway introduz uma epistemologia que possibilita capturar diferencialmente o poder, com o qual faz uma leitura feminista de influência foucaultiana; mas ampliando e transformando a compreensão de Foucault, abrindo-a “a umas políticas positivas e viáveis” (1995, p. 16).

Seguindo a Haraway e sua proposta dos conhecimentos situados, seria importante fazer uma leitura situada de como opera o poder nas sociedades de controle. Se o poder efetivamente tende a se "desterritorializar", a funcionar sem centro e diluir responsabilidades por todo o corpo social, fazendo-se difícil de localizar porque está em 
todas partes da sociedade global, é importante territorializar essa lógica (SANTOS, 2003), concretizando as formas como ela opera e se multiplica. Assim, aproxima-se a possibilidade de entendê-la para diluí-la e construir relações novas, dignas, rebeldes.

\section{Emancipação: na busca de um conceito rebelde}

Assim como as dinâmicas de poder enquanto dominação e controle atravessam praticamente tudo, os micro-processos rebeldes ou contra-hegemônicos também o fazem, embora não seja essa a versão oficial e eles sejam pouco pesquisados. Esses caminhos estão sendo tecidos a cada dia, em formas que também se articulam e crescem, mesmo que não saibamos o quanto eles estão presentes no cotidiano. Como "prova" desses micro-processos que se constroem em práticas, atravessando o cotidiano, a linguagem em uso mostra uma diversidade de palavras associadas a ações de este tipo, como por exemplo: resistência, rebeldia, revolução, subversão, insubordinação, desobediência civil, desobediência popular, contrapoder, antipoder, potência, rebelião, revolta, coletivização, multidão, autogestão, swadeshi (na Índia), auto-organização, anarquismo, comuna, empowerment (potencialização, traduzido como “empoderamento"), agência, poder-fazer, emancipação e tantas outras, que não necessariamente respondem a um modelo cristalizado de sociedade futura.

Entretanto, como bem colocava Rotschild-Whitt em 1979, elas são muito menos mencionadas e estudadas que as relativas ao poder e às formas hegemônicas de organização, ficando marginalizadas na ciência. Vale dizer que, socialmente, as palavras da "galáxia rebelde" têm sido associadas à arruaça e violência, gerando certo medo na coletividade; ou bem são cooptadas, em dinâmicas de governamentalidade, por empresas, governos e a mídia, como é o caso dos programas sociais de construção em "mutirão", ou da autogestão liberal ou "self-management", que dá "liberdade" e "flexibilidade" aos trabalhadores para fazer a produção crescer (LEÓN CEDEÑO, 1999).

Apesar de o campo-tema rebelde ter sido reprimido, banalizado ou cooptado, a multiplicidade de palavras que podem se colocar nele é ampla e relacionada com variadas dinâmicas de poder-dominação-controle. Assim, poderia se parafrasear a revisão de Rojo (2005) sobre a noção de poder e dizer, a partir dela, que "a galáxia rebelde" se apresenta 
dentro de um panorama ambíguo devido a que: 1) tem múltiplas dimensões, sendo plausível destacar algumas esquecendo outras; 2) cada palavra e cada concepção remete a práticas históricas e culturais diferentes, com o qual pode se discordar de alguma abordagem mas não negar que ela faz sentido em algum lugar; e 3) mesmo que não seja tão explícito quanto no caso do poder, também é uma noção inseparável da concepção de sociedade de quem a estiver utilizando: a emancipação pode ser vista como impossível (tal como dizem os autores que proclamam o fim da história), ou como possível apenas se o mundo mudar radicalmente (como defendem os frankfurtianos), ou como sonho de sociedade comunista a ser alcançada via ditadura do proletariado (como sustentam os(as) marxistas, com variações após a queda da URSS e do Muro de Berlim), ou como utopia a realizar no aqui e agora (que é o caso dos(as) anarquistas) ou seria o indicador de espaços de insatisfação que devem ser melhorados para aperfeiçoar o sistema social (que seria uma postura funcionalista).

Por isso, para dar a essas práticas a importância que merecem, para compreender esse emaranhado de forma mais clara e para, compreendendo-o, posicionar-se a respeito, é importante situar não apenas o poder, mas também as ações de revolta, no cotidiano de cada lugar. É preciso contar as histórias de rebelião e reciprocidade que são silenciadas, banalizadas, cooptadas ou reprimidas. E os territórios da linguagem acadêmica devem ser ocupados para teorizar, situadamente, a respeito das múltiplas dinâmicas dessas histórias emancipatórias.

Hardt e Negri (2000) trabalham nesse sentido, colocando e situando historicamente diversas lutas e entendendo-as como motor dos processos de poder, dominação e controle na sociedade global. As revoltas funcionariam como alvos a serem capturados, mas dariam lugar a outras lutas e, no seu acontecer, atacariam diretamente o coração do Império. Contudo, os autores consideram que as revoltas do fim do século XX tiveram pouca repercussão sobre outras lutas; buscando compreender isso, esboçam uma hipótese singular: dizem eles que, no internacionalismo proletário dos séculos XIX e XX, as rebeliões eram comunicadas, "traduzidas" e aplicadas a novos contextos, operando em dimensão internacional; entretanto, as lutas atuais, apesar de ser mais intensas, não reconhecem um inimigo comum contra o qual estariam dirigidas, nem têm construído uma linguagem comum que possa "traduzir" a expressão particular de cada luta em termos que 
façam sentido em outros âmbitos. Com isso, as revoltas perderam em extensão, duração e comunicabilidade, ficando, paradoxalmente, quase incomunicáveis em plena era da comunicação. É um desafio político construir essa língua comum e avançar teoricamente no sentido de um conceito articulador de lutas.

Como essa é uma discussão pouco conhecida na psicologia, e menos ainda a conhecemos como cidadãos e cidadãs comuns, vale a pena narrar brevemente do que se trata. As lutas proletárias dos séculos XIX e XX tinham como premissa a união internacional e a comunicação entre elas, influenciando-se mutuamente. "Um ciclo era construído à medida que uma revolta era comunicada e aplicada a cada novo contexto, da mesma forma que em época anterior navios mercantes levavam notícias de revoltas de escravos de ilha para ilha no Caribe, acendendo uma corrente de fogos impossível de apagar" (HARDT; NEGRI, 2000, p. 69). A formação de um ciclo de lutas implicava que quem recebia as notícias pudesse "traduzi-las" em sua própria língua, reconhecendo as lutas como suas. Por exemplo, os conselhos de fábrica em Turim, Itália, tiveram inspiração direta nas notícias da vitória bolchevique na Rússia.

Os períodos mais intensos desses ciclos foram, segundo os autores, três ondas: a primeira teria começado com a agitação política depois de 1848 e a Primeira Internacional, continuando com a formação de organizações políticas e sindicais socialistas (e anarquistas) nas décadas de 1880 e 1890, e chegando ao seu apogeu após a revolução russa de 1905 e do primeiro ciclo internacional de lutas antiimperialistas. A segunda onda teria surgido após a revolução soviética de 1917, propiciando uma verdadeira explosão de conselhos operários e "uma progressão internacional de lutas que só puderam ser contidas por fascismos de um lado e reabsorvidas pelo New Deal e por frentes antifascistas do outro" (HARDT; NEGRI, 2000, p. 70). Por último, a terceira onda de conflitos começou com a revolução chinesa e continuou com as lutas de libertação latino-americanas e africanas, até a ebulição da década de 60 ao redor do mundo. Esses ciclos de revoltas internacionais foram, segundo Hardt e Negri, o motor que antecedeu, prefigurou e promoveu "os processos de globalização do capital e o nascimento do Império" (p. 70).

Diferentemente, na última metade do século XX, especialmente entre 1968 e a queda do Muro de Berlim, as lutas proletárias e o próprio conceito de proletariado se transformaram. 
"A figura de um ciclo internacional de lutas baseadas na comunicação e tradução dos desejos já parece não existir" (HARDT; NEGRI, 2000, p. 70). Apareceram outras formas de protesto e solidariedade, dentre as quais as mais marcantes do fim do século $\mathrm{XX}$ foram os eventos da praça Tiananmen, na China, em 1989; a intifada palestina contra a autoridade estatal de Israel; a revolta de Los Angeles, EUA, em maio de 1992; o levante em Chiapas, desde 1994; as greves que imobilizaram a França em dezembro de 1995 e a que paralisou a Coréia do Sul em 1996. Cada uma delas expressava questões regionais específicas e imediatas, não sendo uma corrente de revoltas que se espalhava globalmente e, segundo Hardt e Negri (2000), não sendo "traduzíveis" em outros contextos para fazer eco neles e despertar novas lutas.

Aparentemente, essa situação começa a mudar no início do século XXI. Recentemente, surgem movimentos que conectam coletivos dos mais diversos lugares do mundo contra as políticas do Banco Mundial e o Fundo Monetário Internacional, tal como aconteceu em Seattle (1999) e Barcelona (2001), entre outros (BALASCH, 2005), bem como a realização anual do Fórum Social Mundial (com sede principal no Brasil, mas também na Índia e na Venezuela), ocorrendo em época paralela à realização do Fórum Econômico Mundial de Davos. Tais movimentos pretendem articular e dar a conhecer diferentes lutas sob o lema de que "um outro mundo é possível" e reconhecendo como inimigas comuns as políticas econômicas dos grandes bancos internacionais, as corporações transnacionais, o governo dos EUA e o G8. No entanto, este trabalho incipiente e permeado por conflitos ainda tem muito a desenvolver quanto à construção de uma linguagem política comum e a conceitos articuladores de lutas, como expressam Hardt e Negri (2000).

Diversos conceitos são trabalhados desde posições acadêmicas: Hardt e Negri (2000) falam de multidão como cooperação de singularidades, criativa, imanente e em constante movimento, que vai além da noção de proletariado (que hoje se transformou) e que é explorada pelo Império. O Coletivo Situaciones (2001) e Negri (2001) usam o nome contrapoder para se referir às múltiplas práticas de resistência ao poder que criam novas formas de vida e têm como utopia a comuna. Holloway fala de antipoder, entendendo que o contrapoder sugere uma simetria entre poder e contrapoder que não é tal, enquanto o antipoder sugere "uma assimetria total entre o poder e nossa luta" (2001a, p. 77). Foucault disse que onde há poder, há resistência. Tirado (2003, 2004), contrapondo-se à resistência 
como força apenas reativa e não ativa, usa Spinoza e Nietzsche para falar de potência como acontecimento de criatividade coletiva, que se gera na incerteza e que é ontologicamente anterior ao poder porque não precisa dele para operar, enquanto este, para ter ação, busca capturar a potência. Deleuze e Guattari falam de linhas de fuga ao estabelecido, e Guattari (1984) defende a revolução molecular que acontece nos lugares mais diversos: movimentos de mulheres e de homossexuais, hospitais psiquiátricos, rádios livres, creches, gangues nova-iorquinas, inclusive partidos políticos e sindicatos.

O trabalho de sistematização dos múltiplos termos e experiências deste campo-tema vai sendo executado aos poucos. Excelentes exemplos disso são o "Pequeno Léxico Filosófico do Anarquismo", de Daniel Colson (2003), uma espécie de dicionário da proposta libertária e seus diferentes projetos, e, por outro lado, o projeto de pesquisa "A Revisão da Emancipação Social”, coordenado por Boaventura de Sousa Santos, em 2002, compilado em sete volumes e realizado em seis países (Moçambique, África do Sul, Brasil, Colômbia, Índia e Portugal). Ambos os trabalhos usam a noção de emancipação como palavra-chave para afirmar formas de vida que não se pautam por valores hegemônicos de dominação e controle, em práticas que têm acontecido no decorrer da história e que continuam acontecendo no aqui e agora.

O argumento emancipatório de Boaventura de Sousa Santos (2003) é que as experiências sociais no mundo todo são muito mais numerosas, variadas e interessantes do que a ciência hegemônica consegue enxergar; no entanto, essa experiência está sendo desperdiçada, o que dá lugar a explicações fatalistas como o fim da história e a ausência de alternativas. Assim, para combater o desperdício da experiência social e fazer jus às iniciativas e movimentos existentes, é preciso construir uma ciência para além da hegemônica; mais do que isso, é necessário construir uma outra racionalidade. Portanto, a emancipação social implica emanciparmo-nos da racionalidade ocidental. E avançar nisso é conceber o tempo de forma diferente, esticando o presente e encurtando o futuro. Não temos certeza de se um outro mundo é possível, mas o único que nos resta é construir formas ou micro formas desse mundo no presente e nas expectativas concretas e situadas de futuro.

Reconhecer a tutela da racionalidade ocidental, daquilo que CECOSESOLA (2001) denomina "nossa cultura patriarcal", seria, para Santos (2003), construir uma "sociologia 
das ausências" para entender as ausências que essa racionalidade tem gerado e criticá-las, combatendo-as com o reconhecimento desses outros jeitos de fazer que têm sido colocados em posições subalternas: saberes práticos, senso comum, temporalidades rurais ou outras marginalizadas; saberes de pessoas excluídas por marcas como a raça, o gênero, a classe social ou a opção sexual; saberes que escapam à concepção supostamente universal e por isso são vistos como locais, exóticos, folclóricos e formas de produção alternativas às formas dominantes de economia. Estudar as ausências facilitaria entender os medos que a racionalidade ocidental tem ajudado a construir - medo à diferença que se encontra nesses saberes menosprezados, por exemplo - e trabalhar neles, olhando-os fixamente, até diluí-los.

Intensificar e alongar o presente pode facilitar-se com o movimento de encurtar o futuro, que para Santos (2003) seria propiciado, desde a ciência, por uma "sociologia das emergências": estudar possibilidades concretas de futuro e fazê-las realidade seguindo os sinais ou pistas que aparecem no cotidiano, pois elas podem indicar possibilidades mais plenas para abrir caminhos, ou necessidades de pôr limites e fechar portas. Já que não se tem a certeza de um outro mundo ser possível, sua construção em ações do dia-a-dia seria um microprocesso em que o futuro seria tratado como objeto de cuidado, revisando o feito nos pequenos detalhes, na sua capacidade de afirmar vida diferente e de negar qualquer dominação, presente ou futura, que atravesse ou constitua as pessoas.

Para formar forças contra-hegemônicas mais potentes, é importante criar e aprofundar zonas de contato entre distintos saberes e ajudar a fazê-los inteligíveis entre si, em um processo que Santos, assim como Hardt e Negri (2000), denomina tradução. Usar essa tradução de forma responsável e horizontal nos ajuda a fazermo-nos mais fortes e aprendermos outras formas de agir e, portanto, de ser. Para isso, o autor defende a importância de se entender as regras do jogo de cada saber não como sendo óbvias ou homogêneas, mas como argumentos que vale a pena aprender, discutir e reconstruir. Outrossim, ele coloca a dificuldade de qual a língua a ser usada para diferentes saberes se entenderem, devido a toda a opressão que pode significar para alguém oprimido(a) ter de falar a língua dominante. Pode ser útil, nesses casos, entender-se mutuamente a partir de outras línguas, como a dança e a expressão corporal, que possibilitam encontros inusitados, ações de auto-cuidado e de ajuda mútua.

CADERNOS GESTÃo PÚBLICA E CIDADANIA, v. 12, N.51 - JUL./DEZEMBRO 2007 
Essas seriam formas de se construir conhecimento-emancipação (SANTOS, 2003) que devem ser valorizados para ajudar a reverter a marginalização e a ausência com que têm sido tratados. O "ponto de saber" do conhecimento-emancipação seria a solidariedade ou ajuda mútua, e seu "ponto de ignorância" seria o colonialismo. Santos destaca esta vertente de conhecimento como sendo chave para gerar formas de vida menos absurdas que as atuais, mas salienta que a ciência moderna - bem como vida moderna - tem se dedicado a ela de forma marginal e, principalmente, tem produzido "conhecimento-regulação" que tem, como ponto de ignorância, o "caos", e como ponto de saber, "a ordem".

Para o autor, estas duas vertentes de conhecimento são fundamentais e, em alguma medida, uma ajuda a constituir a outra; por exemplo, todo conhecimento-emancipação tem implícita alguma forma de regulação, provavelmente de auto-regulação. Sendo assim, se o conhecimento-regulação trabalha conjuntamente com o conhecimento-emancipação, em qualidade de ferramenta emancipatória, pode ser útil. Mas acontece que, segundo Santos (2000), o conhecimento emancipatório foi gradativamente engolido pelo regulatório, justificando essa desigualdade ao se equiparar "caos" com "solidariedade" e, em alguma medida, "ordem" com "colonialismo".

Segundo Mignolo (2003), tal reversão poderia ser feita através de um programa "forte", que se referiria à criação de um novo senso comum, emancipatório, ou bem ser empreendida através de um programa mais suave que implique na articulação de múltiplas formas situadas de conhecimento. É com esta segunda visão que Mignolo concorda: com uma rede de saídas micro em lugar de optar por uma saída forte, radical e até unívoca. Este texto também concorda com um mundo onde caibam muitos mundos, como dizem os zapatistas. Parece ser nesse sentido que Santos (2001) fala de uma "globalização contra-hegemônica", no sentido de que a opção não é apenas uma, mas muitas que se articulam: segundo texto do Coletivo Situaciones, "a força da resistência radica na destotalização e na multiplicidade" (Coletivo Situaciones, 2001, p. 33).

Ante a idéia de uma rede de saídas micro, é pertinente relembrar a proposta anarquista de Mikhail Bakunin, que, defendendo a posta em prática de uma rede ou federação de comunas, aponta para uma utopia livre e igualitária que se constrói todos os dias. Bakunin defendia que a revolução seria a emancipação completa da sociedade, sem ditaduras 
proletárias nem hierarquias de Estado nem mercado; tal emancipação basear-se-ia em duas premissas fundamentais, que são a liberdade plena de todos os seres humanos e a solidariedade de todos os trabalhadores e trabalhadoras entre si:

E a primeira palavra dessa emancipação só pode ser liberdade, não essa liberdade política, burguesa (...), mas a grande liberdade humana que, destruindo todas as correntes dogmáticas, metafísicas, políticas e jurídicas pelas quais todo mundo se encontra hoje oprimido, devolverá a todos, coletividades tanto quanto indivíduos, a plena autonomia de seus movimentos e de seu desenvolvimento, libertos, de uma vez por todas, de todos os inspetores, diretores e tutores.

A segunda palavra dessa emancipação é solidariedade; não a solidariedade marxista, organizada de cima para baixo por um governo qualquer e imposta seja pela astúcia, seja pela força, às massas populares; não essa solidariedade de todos, que é a negação da liberdade de cada um, e que por isso mesmo se torna mentira, ficção, tendo por substituto real a escravidão; mas a solidariedade que é, ao contrário, a confirmação e realização de toda liberdade, originando-se não em uma lei política qualquer, mas na própria natureza coletiva do homem, em virtude da qual nenhum homem é livre se todos os homens que o cercam e que exercem a mínima influência, direta ou indireta, sobre sua vida, não o são igualmente (2001, p. 43-44).

Vindo de Bakunin, essa utopia no aqui e agora não deve ser entendida como uma única forma de liberdade e de solidariedade, que se cristaliza e se faz estática quando alcançada. Seria mais apropriado pensar em uma federação de pequenas utopias que se realizam no aqui e agora em meio à diversidade, à contradição e às formas de poder, dominação, sujeição e controle que têm nos moldado como seres humanos durante séculos. Haverá conflito sempre e é saudável que assim seja. Mas a idéia é trabalharmos para que os conflitos sejam cada vez menos mesquinhos, mais solidários, mais inteligentes. E 
justamente a característica do projeto libertário de federar forças diferentes e contraditórias, cada uma agindo de forma situada no seu lugar, age, segundo Colson, como certa garantia para diluir "as armadilhas das relações próprias de cada dominação, produzidas por essa dominação" (2003, p. 74). Se a idéia de globalização contra-hegemônica de Santos (2001) e de tantos movimentos sociais for nesse sentido, bem-vinda seja.

Para o presente artigo contribuir de forma efetiva com o que Bakunin, Santos e Colson (2003) denominam emancipação, é preciso trabalhar reconhecendo ausências, apontando emergências e "traduzindo" saberes. Por isso, convém trabalhar as discussões teóricas sobre a emancipação, a "galáxia rebelde" e suas múltiplas palavras e experiências a partir da conexão com iniciativas igualitárias e suas práticas cotidianas, para aprender a respeito. Pode se dizer que essas vozes têm estado ausentes da ciência hegemônica e das diretrizes político - econômicas mundiais. Aprendendo desses saberes marginalizados, podem se pensar práticas concretas, formas situadas de futuro, para vê-lo como objeto de cuidado. E articulando suas ações em conceitos e práticas-chave comuns, que respeitem sua diversidade e múltipla riqueza de experiências, talvez possam se expandir possibilidades de ação emancipatória. 


\section{Referências bibliográficas:}

ADORNO, T.: Relación entre sociología e psicología. Barcelona: Paidós, 1991. \& HORKHEIMER, M.: O conceito de esclarecimento. In: Dialética do Esclarecimento. Rio de Janeiro, Jorge Zahar, 1985.

ARDITI, J.: Analítica de la postmodernidad. Prólogo de HARAWAY, D.: Ciencia, cyborgs y mujeres. La reinvención de la naturaleza. Valencia: Cátedra, 1995.

BAKUNIN, M.: Escritos contra Marx. São Paulo, Imaginário/Soma/Nu-Sol, 2001.

BALASCH, M.: Prácticas postidentitarias: una comprensión situada de las relaciones ente gobernabilidad y acción política. Trabalho de pesquisa para a obtenção da "suficiência investigadora”. Barcelona: Universidade Autônoma de Barcelona, 2005.

BAUMAN, Z.: Modernidade líquida. Rio de Janeiro, Jorge Zahar, 2001.

CALLÉN, B.: Virtualización de los afectos. Trabalho de curso de Doutorado em Psicologia Social. Barcelona, Universidade Autônoma de Barcelona: mimeo, 2005.

e TIRADO, F.: “Imperio y Multitud: la transformación de la gobernabilidad

en los espacios virtuales. Scripta Nova. Revista electrónica de Geografía y Ciencias Sociales. Barcelona, Universidad de Barcelona, 011/08/2004, vol. VIII, No. 170 (46).

CECOSESOLA - Escola Cooperativa Rosario Arjona: Hacia una convivencia armónica. Barquisimeto, CECOSESOLA, 2001 (cecosesola@ cantv.net - Fone: 0058251-237-29-09).

CHOMSKY, N.: Notas sobre o anarquismo. São Paulo, Editora Imaginário - Sedição Editorial, 2004.

COLECTIVO SITUACIONES: Por una política más allá de la política. In: NEGRI, T.; MATTINI, L.; BENASAYAG, M.; COLETIVO SITUACIONES; GONZÁLEZ, H.; HOLLOWAY, J. e BRAND, U. (2001): Contrapoder. Una introducción. Buenos Aires: De mano en mano, 2001. 
COLSON, D.: Pequeño léxico filosófico del anarquismo. Buenos Aires: Nueva Visión, 2003.

CONSULTA SOCIAL EUROPEA: Ecologia $i$ medi ambient: qüestions de consum responsable. Barcelona, mimeo, 2004 (página web: www.consultaeuropea.org).

CROCHIK, J.L.: Filosofia da Ciência. Disciplina de Doutorado em Psicologia Social. São Paulo, PUC-SP, março a junho de 2002.

DELEUZE, G.: Post-scriptum sobre as sociedades de controle. In: DELEUZE, G.: Conversações: 1972-1990. Rio de Janeiro: Ed. 34, 1992, pp. 219-226.

EGO DUCROT, V.H.: Iraq y la siniestra lógica de Estados Unidos en su estrategia de Guerra Global. Disponível em: www.soberania.org, Acessado em: 11 janeiro 2006. Publicado em 02/04/03.

FERREIRA, A.B.H.: Novo dicionário básico da língua portuguesa. São Paulo, Nova Fronteira, 1995.

FIC - FRACTALIDADES EN INVESTIGACIÓN CRÍTICA: Investigación crítica: desafíos y posibilidades. In: Athenea Digital, 8, outono 2005, 29-144. Disponível em: <http://antalya.uab.es/athenea>. Acesso em: 10 de novembro 2005.

FOUCAULT, M.: Vigilar y castigar. Madri, Siglo XXI Editores S.A, 1976. : La gubernamentalidad. In: Saber y poder. Madri: La Piqueta, 1978.

GONZÁLEZ BALLETBÓ, I.: Sobre nuestras concepciones. Comunicação pessoal via email. Mensagem recebida por aiasvenez@yahoo.com em 15 de agosto 2005.

GRAMSCI, A: Os intelectuais e a organização da cultura. Rio de Janeiro, Civilização Brasileira, 1978.

GUATTARI, F.: A revolução molecular. São Paulo: Brasiliense, 1984.

: Plan sobre el planeta. Capitalismo mundial integrado y revoluciones moleculares. Madri, Virus, 2004. 
HARAWAY, D.: Ciencia, cyborgs y mujeres. La reinvención de la naturaleza. Valencia: Cátedra, 1995.

: Las promesas de los monstruos: una política regeneradora para otros inapropiados/bles. Política y Sociedad, 30, 1999, pp.121-163. Madrid.

HARDT, M. e NEGRI, A: Império. Rio de Janeiro: Record, 2000.

HOBSBAWM, E.J.: Rebeldes primitivos. Rio de Janeiro, Zahar, 1970.

HOLLOWAY, JOHN: Doce tesis sobre el antipoder. In: NEGRI, T.; MATTINI, L.; BENASAYAG, M.; COLETIVO SITUACIONES; GONZÁLEZ, H.; HOLLOWAY, J. e BRAND, U.: Contrapoder. Una introducción. Buenos Aires: De mano en mano, 2001a. : Por un enfoque negativo, dialéctico, anti-ontológico. In: NEGRI, T.; MATTINI, L.; BENASAYAG, M.; COLETIVO SITUACIONES; GONZÁLEZ, H.; HOLLOWAY, J. e BRAND, U.: Contrapoder. Una introducción. Buenos Aires: De mano en mano, 2001b.

LEÓN CEDEÑO, A: Guia múltiplo da autogestão. Dissertação de Mestrado em Psicologia Social. São Paulo: PUC-SP, 1999.

LLAMAS, R.: Teoría torcida. Prejuicios y discursos en torno a "la homosexualidad". Madrid: Siglo XXI Editores, 1998.

LUKES, S.: Poder: uma visão radical. São Paulo, Cortez, 1985.

- MATTA, G.: A medida política da vida: a invenção do WHOQOL e a construção de políticas de saúde globais. Tese de Doutorado em Saúde Coletiva. Rio de Janeiro: UERJ, Instituto de Medicina Social, 2005.

McROBBIE: Post-marxism and cultural studies: A post-cript. In: GROSSBERG, L, NELSON, C. e TREICHLER, P. (Orgs.): Cultural Studies. London, Routledge, 1992.

MIGNOLO, W.: Os esplendores e as misérias da "ciência": colonialidade, geopolítica do conhecimento e pluri-versalidade epistêmica. In: SANTOS, B.S. (Org.): Conhecimento prudente para uma vida decente. "Um discuso sobre as ciências" revisitado. São Paulo, Cortez, 2003. 
NEGRI, A: Contrapoder. In: NEGRI, T.; MATTINI, L.; BENASAYAG, M.; COLETIVO SITUACIONES; GONZÁLEZ, H.; HOLLOWAY, J. e BRAND, U: Contrapoder. Una introducción. Buenos Aires: De mano en mano, 2001.

PASSETTI, E.: Anarquismos e sociedade de controle. São Paulo, Cortez, 2003.

PERKINS, J.: Confissões de um assassino econômico. São Paulo: Cultrix, 2005.

ROJO, R.E.: Por una sociología jurídica del poder y la dominación. In: Sociologias, No. 13. Porto Alegre, Jan-Jun 2005.

ROMERO BACHILLER, C., GARCÍA DAUDER, S. e BARGUEIRAS MARTÍNEZ, C. (2005): El eje del mal es heterosexual. Figuraciones, movimientos y prácticas feministas queer. Madri: Traficantes de Sueños, 2005.

ROSE, N.: Inventing our selves: Psychology, power and personhood. Nova Iorque: Cambridge University Press, 1996.

: Powers of freedom: Reframing political thought. Cambridge: Cambridge University Press, 1999.

ROSEMBERG, F.: Literatura infantil e ideologia. São Paulo, Global, 1984.

: Educação, classe, raça e gênero. Cadernos de Pesquisa, São Paulo, No. 96, p. 58-65, fev. 96.

: O conceito de ideologia nas ciências sociais. Curso de Doutorado em Psicologia Social. São Paulo, PUC-SP, 2002.

ROTSCHILD-WHITT, J: "The collectivist organization: na alternative to rationalbureaucratic models”. American Sociological Review 1979, Vol. 44 (agosto): 509-527.

SANTOS, B.S.: Crítica da razão indolente: contra o desperdiço da experiência. São Paulo, Cortez, 2000.

: Os processos da globalização. Eurozine -The magazine. Disponível em: <http://wwww.eurozine.com/article/2002-08-02-santos-pt.html> Acesso em: 14 de fevereiro 2005. Publicado em 2002. 
: Para uma sociologia das ausências e uma sociologia das emergências. In:

SANTOS, B.S. (Org.): Conhecimento prudente para uma vida decente. "Um discuso sobre as ciências" revisitado. São Paulo, Cortez, 2003.

SEMERARO, A: Gramsci e a sociedade civil. Cultura e educação para a democracia. Petrópolis, Vozes, 1999.

SETHI, H.: Swadeshi em debate na Índia. In: SANTOS, B.S. (org.): Conhecimento prudente para uma vida decente. "Um discurso sobre as ciências" revisitado. São Paulo: Cortez, 2003.

SHIVA, V.: Biopirataria. A pilhagem da natureza e do conhecimento. Petrópolis: Vozes, 2001.

SPINK, P.: "Pesquisa de campo em psicologia social: uma perspectiva pósconstrucionista”. Psicologia e Sociedade, 15 (2): 18-42; jul./dez. 2003.

: Organizações e ação social. Orientações coletivas de Mestrado e Doutorado no núcleo de pesquisa “Organizações e Ação Social”. São Paulo: PUC-SP, 2005.

TIRADO, F.: Los objetos y el acontecimiento: teoría de la socialidad mínima. Tese de Doutorado em Psicologia Social. Barcelona: Universidade Autônoma de Barcelona, 2001.

: Tecnociencia y pensamiento social. Del individuo al dividuo. Curso de doutorado em Psicologia Social. Barcelona: Universidade Autônoma de Barcelona, 2003.

: Tecnociencia y poder. Curso de doutorado em Psicologia Social. Barcelona: Universidade Autônoma de Barcelona, 2004.

THOMPSON, E.P.: Costumes em comum. São Paulo: Companhia das Letras, 1998.

THOMPSON, J.: Ideologia e cultura moderna. Teoria social crítica na era dos meios de comunicação de massa. Petrópolis: Vozes, 1995.

Artigo recebido em: 10/05/ 2007 e aceito em 12/08 /2007. 